\title{
Consumers' Attitude towards Digital Social Responsibility: Impacts on Electronic Word of Mouth and Purchase Intention
}

\author{
Wilert Puriwat ${ }^{1}$, Suchart Tripopsakul ${ }^{2 *}$ \\ ${ }^{1}$ Chulalongkorn Business School, Chulalongkorn University, Bangkok, 10330, Thailand. \\ ${ }^{2}$ School of Entrepreneurship and Management, Bangkok University, Bangkok, 10110, Thailand.
}

\begin{abstract}
Social responsibility is understood to be one of the crucial strategic responsibilities for organizations across the globe. In the digital era, firms have transformed social responsibility initiatives into digital platforms. This study aims to investigate the effects of digital social responsibility (DSR) on electronic word of mouth (eWOM) and purchase intention (PI) in the social media context. This survey research is based on 214 samples, collected via an online questionnaire as a research tool. Structural equation modelling has been used to validate the proposed hypotheses. The results show that perceived DSR has significant positive influence on consumers' attitude $(b=0.408)$ and eWOM $(b=0.238)$. The mediation analysis indicates that consumers' attitude partially mediates the relationship between DSR and eWOM (DE $=0.238$, IE $=0.154)$, and fully mediates the relationship between DSR and PI $(\mathrm{DE}=0.08, \mathrm{IE}=0.173)$. Since few previous studies have explored the impact of DSR toward eWOM and PI, our study confirms the effects of DSR on consumers' attitudes and eWOM. This empirical study can provide managers with further understanding of the effects of DSR via social media on consumers' attitude and eWOM. Our results should also encourage firms to implement DSR initiatives to enhance consumers' positive attitudes and spread positive word of mouth about firms.
\end{abstract}

\section{Keywords:}

Digital Social Responsibility;

Electronic Word of Mouth;

Purchase Intention;

Social Media.

\section{Article History:}

Received: $\quad 17 \quad$ September 2021

Revised: $\quad 09 \quad$ November 2021

Accepted: 03 December 2021

Published: $01 \quad$ February 2022

\section{1- Introduction}

Social responsibility has been acknowledged as one of the imperative strategic actions for firms. Businesses can gain market advantages by developing positive relationships with customers and other stakeholders. Furthermore, businesses have legal and economic responsibilities to participate in improving society [1]. Social responsibility addresses a business's long-term value through relationships with multiple stakeholders, including customers, shareholders, and the workforce. According to prior research conducted by Öberseder et al. [2], social responsibility exerts an influence on relevant parameters, such as consumers' attitude, satisfaction, purchase intention, and brand loyalty. Moreover, social responsibility can enhance corporate performance and reputation, and improve product evaluations; thus, it has become a prevalent marketing strategy worldwide [3].

The advancement of technologies for information, communications, and online social networking has changed the way people live and communicate globally. In comparison with conventional media, social media communication is more vibrant and incurs less cost. Social media possesses wide potential in terms of technology, enabling participants to widen communication processes, increase interactions among businesses and audiences in a program, and accordingly enhance direct interactions [4].

\footnotetext{
* CONTACT: suchart.t@bu.ac.th
}

DOI: http://dx.doi.org/10.28991/ESJ-2022-06-01-05

(C) 2022 by the authors. Licensee ESJ, Italy. This is an open access article under the terms and conditions of the Creative Commons Attribution (CC-BY) license (https://creativecommons.org/licenses/by/4.0/). 
Social networking sites have shaped virtual communities where individuals can have conversations, actively participate in discussions, acquire knowledge on trending issues, and express their opinions in a free and fair manner. Today's customers are equipped with advanced internet technology and mobile phones, leveraged to express their opinions and bring changes that influence their lives. Further, social media helps in delivering imperative information both on-demand and voluntarily according to the requests of others [5].

We are Social [6] published the Global Digital Report 2020, which provides further insight into mobile technology and its penetration in Thailand. According to this report, Thailand has a total of 52 million mobile internet users, out of a population totaling 70 million: in effect, a $75 \%$ penetration rate. The report further reveals that 52 million people actively use social media through the internet, and that $97 \%$ of internet users in Thailand use mobile internet. In addition, a Thai user spends an average of 9 hours daily on the internet. In terms of access to internet banking services, Thailand holds the top position globally, with $74 \%$ of its population having access, followed by Sweden with $71 \%$ and Turkey with 68\%. An additional survey conducted among global users in the age range of 16-64 during the second and third quarters revealed that Facebook (93\%), YouTube (91\%), Line (84\%), Facebook Messenger (72\%) and Instagram (65\%) are the five top-most active social networking sites accessed by internet users [7].

Digital social responsibility (DSR) is widely accepted as an important strategy for businesses. However, according to prior literature, few researchers have investigated the impacts of DSR upon purchase intention (PI), consumers' attitudes (ATT), and electronic word of mouth (eWOM). Consequently, the purpose of this study is to investigate the impacts of DSR on customers' attitude, eWOM, and purchase intention. The outcome of our study will help firms to redefine their social responsibility strategies and improve understanding of the dynamic of corporate social responsibility communication in the digital era.

The remaining sections of this paper are organised as follows: Section 2 concentrates on related literature regarding DSR, eWOM, consumers' attitude, and purchase intention, providing a proposed conceptual framework and developing related hypotheses. Section 3 provides details of the research methodology and data collection. Section 4 presents data analysis, results, and discussion. Section 5 postulates a conclusion, discusses limitations, and provides recommendations for future research.

\section{2- Literature Review}

\section{2-1-Digital Social Responsibility (DSR) in the Social Media Context}

Social media platforms, including Twitter, Facebook, and Instagram, among others, have emerged during the past decade as useful networks enabling organizations to connect with their consumers and stakeholders [8, 9]. The advancement of internet technology has transformed previously offline corporate social responsibility initiatives and activities into online and virtual corporate social responsibility (CSR) - DSR. Previous studies indicate that the use of interactive media is able to improve the effectiveness of communication about social responsibility [10]. DSR can be defined as any endeavours, initiatives or activities by an individual, group, or organization to undertake and implement a CSR concept via online or digital platforms. Specific to social media, DSR can be defined as the threshold at which consumers make use of social media in engaging with organisations' social responsibility communications. Further, DSR also defines consumer engagement with firms' social responsibility activities through social media; for example, likes, shares, and comments on Facebook.

Social networking sites have emerged as among the most effective platforms for organizations to implement DSR [11]. Farzin and Fattahi have stated that companies with higher CSR rates tend to establish increased online presence, for example having a higher number of Facebook page followers than companies with lower CSR rates [12]. Moreover, Tao and Wilson have shown that Facebook is the most popular social media network used to implement DSR compared with other social sites [13]. Organizations of various business sizes and types have begun heavily using this form of media in order to implement and communicate their social responsibility activities [11]. Leveraging social media to execute DSR enhances the effectiveness of firms' social engagement as a result of the ease of sharing initiatives and activities with the community. Moreover, Fatma et al. have stated that implementation of DSR via social media is predicted to play an important role in CSR concepts [14]. DSR can be implemented with higher speeds and lower costs than CSR communication in such traditional media as television, print and radio.

\section{2-2-Electronic Word of Mouth (eWOM)}

The conventional word of mouth (WOM) concept has shifted into eWOM. Prior studies have revealed the relationship between firms' social responsibility initiatives and customers' positive WOM $[15,16]$. Bhattacharya and Sen have stated that the willingness of a consumer to talk positively about a firm which is engaged in social responsibility activities, is one of the important behavioural outcomes in CSR activities [17]. According to Lacey and Kennett-Hensel [18], a consumer exhibits positive WOM if he or she prefers to share favourable communication about a company to others. WOM impacts a lot of attributes such as awareness, behaviour intention, actual purchase behaviour in both offline and online modes, attitudes, and perceptions. 
Litvin et al. have defined eWOM as an informal communication from a company, directed at customers via internetbased technologies about the features of a product or service [19]. Further, Hennig-Thurau et al. have defined eWOM as any sort of statement, either positive or negative, made by prospective or existing customers about goods or firms, which is spread to reach crowds of people and organizations through the assistance of information and communications technologies [20].

According to Fatma et al., in comparison with conventional offline WOM, several advantages are associated with eWOM via social media; for example, information can be quickly and spontaneously disseminated. This electronic strategy can also be utilised to establish firms' shared values for social responsibility [14].

\section{2-3-Consumers' Attitude and Purchase Intention}

Previous studies have confirmed positive associations between consumer attitude and purchase intention in social media contexts [21, 22]. According to Boone and Kurtz (2004), attitude is described as a person's emotions, favourable or unfavourable assessments, or action tendencies towards an object or information [23]. The attitude of a person can enable observers to understand their psychological tendencies, as well as their likes and dislikes towards an object or topic. A person's attitude has the potential to impact their judgement, their information processing, and their resulting behaviour. Prior research has confirmed interrelationships between consumers' attitudes and their purchase intentions. The chances of purchasing a product are high among individuals with positive attitude, indicated by either liking or disliking the product.

Thus, purchase intention remains a crucial indicator for organisations [24]; it enables companies to predict whether a consumer will purchase their product within a given time. This factor also functions as a representative for actual behaviour [25]. According to Green and Peloza, consumers' purchasing decisions are further influenced by social responsibility, when a brand's products or services include ethical offerings and its products demonstrate commitment to protect consumers' interests [26]. Furthermore, Creyer and Ross have argued that the purchase-decision processes of a customer involve social responsibility initiatives, among other important factors [27].

See-To and Ho have mentioned that eWOM has a direct influence on consumers' purchase intention [28]; it influences consumers' trust towards the firm and its products. According to Creyer and Ross, buyers consider businesses' behaviours, both moral and deceptive, when determining whether to make a purchase [27]. Moreover, customers expect businesses to exhibit high morals, and are more likely to avoid businesses which do not. Implementing DSR to spread a message of morality can positively influence consumers' attitude, resulting in positive eWOM and eventually creating an impact on overall purchase intention.

\section{2-4- Conceptual Framework and Hypotheses}

Based upon review of the existing research in this domain, the below research framework has been developed to examine the effects of DSR via social platforms on eWOM and purchase intention. The researcher has proposed a total of eight hypotheses, listed below. Figure 1 shows the proposed model for the research framework.

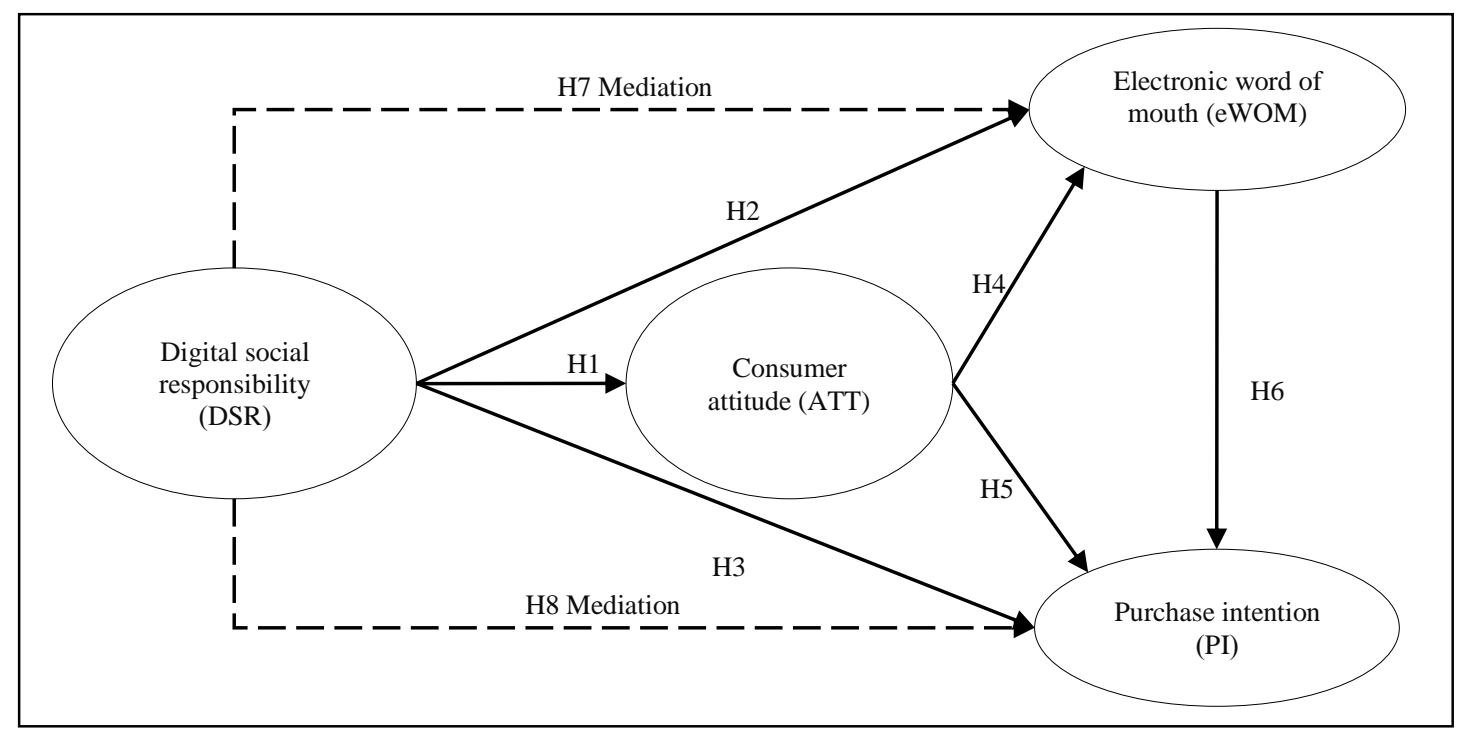

Figure 1. The proposed conceptual research framework 
The following hypotheses have been developed to examine the relationships among the model constructs:

H1: Digital social responsibility (DSR) initiatives have a direct effect on consumer attitude (ATT).

H2: Digital social responsibility (DSR) initiatives have a direct effect on electronic word of mouth (eWOM).

H3: Digital social responsibility (DSR) initiatives have a direct effect on purchase intention (PI).

H4: Consumer attitude (ATT) has a direct effect on the electronic word of mouth (eWOM).

H5: Consumer attitude (ATT) has a direct effect on purchase intention (PI).

H6: Electronic word of mouth (eWOM) has a direct effect on purchase intention (PI).

H7: Digital social responsibility (DSR) significantly indirectly influences electronic word of mouth (eWOM), as mediated by consumer attitude (ATT).

H8: Digital social responsibility (DSR) significantly indirectly influences purchase intention (PI), as mediated by consumer attitude (ATT).

\section{3- Research Methodology}

\section{3-1-Research Design and Data Collection}

As discussed earlier, the current study aims to analyse the influence of DSR on eWOM and purchase intention in the context of social media. This paper has adopted quantitative methods to analyse the proposed hypotheses. The researcher has developed a questionnaire to determine DSR, consumer attitude, eWOM, and purchase intention. AMOS 20.0 was used for structural equation modelling to examine the data, check the proposed hypotheses, and assess the significance of theories as well as positive correlation of variables.

Purposive sampling was used to distribute an online self-administered questionnaire via Google Forms to Thai Facebook users. The suggestions from Anderson and Gerbing [29] designated 150 as the minimum sample size for a study, while 200 was recommended as acceptable sample size for SEM analysis [30]. Because this study mainly uses SEM, a minimum sample size of 200 was targeted for data collection. In order to confirm the eligibility of samples, potential respondents were screened initially through three questions. First, respondents were asked, "Do you have a Facebook account that you have accessed during the last month?" The second question was, "Do you follow any company's official fan page on Facebook?" The third question was, "Have you ever seen any posts on Facebook which explicitly refer to the organisation's donation or granting of money to a charitable cause, volunteer efforts, or involvement in the communities in which it operates?" The researcher scrutinized only those participants who responded 'yes' to all three initial screening questions, and authorized those who passed the screen to participate in the actual survey. Participants were asked to recall and update their answers in the survey questionnaire based on their perception of DSR programmes on social platforms. In total, 231 questionnaires were returned. After checking the completion of questionnaires, 214 applicable surveys were retained for further evaluation. Figure 2 represents the research procedure.

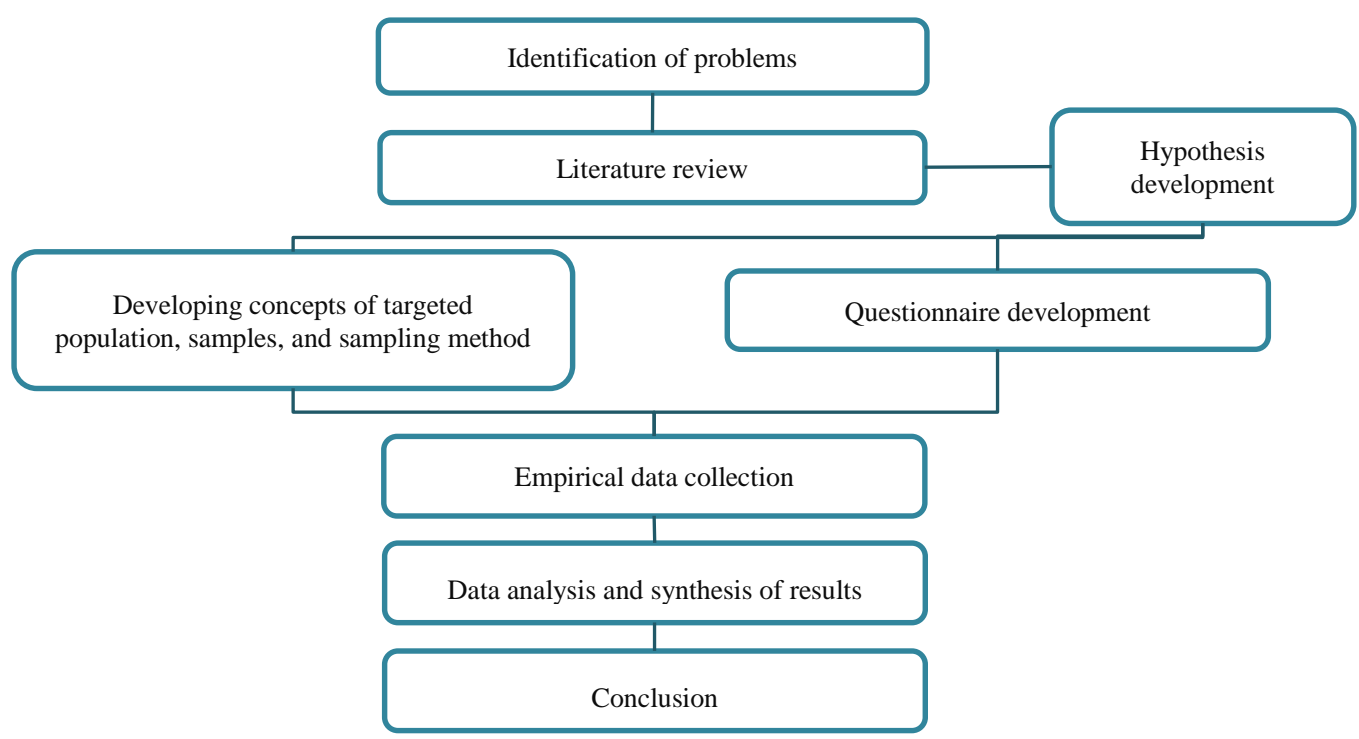

Figure 2. Flow chart of the research methodology 


\section{3-2-Questionnaire Development and Pre-test Analysis}

The questionnaire contained three sections: (1) preliminary screening questions; (2) general information regarding demographic and behavioural characteristics of the participants; and (3) items measuring the constructs. The current study has developed measurement items based on previous studies. A five-point Likert scale has been employed to measure each item, ranging from '1-strongly disagree' to '5-strongly agree'. DSR, the independent variable in the proposed model, has been measured with a five-item scale adapted from Butt [31]. To evaluate ATT, the researcher considered a six-item scale based on the work of Chu and Chen [3] and Herrero and Martínez [32]. To measure eWOM, this study uses a six-item scale from the literature of Chu and Chen [3] and Kwok et al. [33]. Based on the work of Tien et al. [34], PI has been evaluated using a three-item scale. Table 1 shows all the scale items used in the study; the measurement scale questions posed in the study comprise 20 items.

After defining the questionnaire constructs and questions, the researcher obtained reviews of the items from three experts, each with at least 5 years of experience teaching marketing, to verify content validity. Furthermore, the index of item-objective congruence (IOC) by Rovinelli and Hambleton [35], as cited in Turner and Carlson [36], was examined. The IOC values of those 20 items lie in the range of $0.67-1.00$, which is above the recommended minimum value of 0.5 , and was thus considered to indicate reliable content validity. A pilot study was conducted among undergraduate students, and the resulting pilot data were used to assess the validity and understandability of the scale items [37]. Cronbach's $\alpha$ has been employed to estimate the reliability; it was in the range of 0.7 or higher for all variables, thus confirming the questionnaire's reliability. Table 1 provides the details of the questionnaire.

Table 1. Details of the questionnaire constructs and questions

\begin{tabular}{|c|c|c|}
\hline Constructs & Items & Observed Variables \\
\hline \multirow{5}{*}{$\begin{array}{l}\text { Digital Social } \\
\text { Responsibility (DSR) }\end{array}$} & DSR1 & I feel that the digital social responsibility record of brand [NAME] is good. \\
\hline & DSR2 & Brand [NAME] is a digital social responsibility. \\
\hline & DSR3 & $\begin{array}{l}\text { Regarding the social issues, brand [NAME] is really trying to implement DSR to help solving } \\
\text { social problems. }\end{array}$ \\
\hline & DSR4 & $\begin{array}{l}\text { Regarding the environmental issues, brand [NAME] is really trying to implement DSR to } \\
\text { communicate to its customer about its environmental practices and protections. }\end{array}$ \\
\hline & DSR5 & $\begin{array}{l}\text { Regarding the economic issues, brand [NAME] is really trying to implement DSR to build solid } \\
\text { relations with its customers to assure its long-term economic success. }\end{array}$ \\
\hline \multirow{6}{*}{$\begin{array}{l}\text { Customers' Attitude } \\
\text { (ATT) }\end{array}$} & ATT1 & I think it is a good idea to like, share, and comment on [NAME]'s DSR initiatives on SNSs. \\
\hline & ATT2 & I like the idea of liking, sharing, and commenting on [NAME]'s DSR initiatives on SNSs. \\
\hline & ATT3 & It seems interesting to like, share, and comment on [NAME]'s DSR initiatives on SNSs. \\
\hline & ATT4 & My attitude toward brand [NAME] is good. \\
\hline & ATT5 & My attitude toward brand [NAME] is positive. \\
\hline & ATT6 & My attitude toward brand [NAME] is favourable. \\
\hline \multirow{6}{*}{ eWOM (EW) } & EW1 & I would "Like" those brand [NAME]'s DSR initiatives and messages. \\
\hline & EW2 & I would "Share" those brand [NAME]'s DSR initiatives and messages. \\
\hline & EW3 & I would “Comment" those brand [NAME]'s DSR initiatives and messages. \\
\hline & EW4 & I am likely to spread positive word of mouth about brand [NAME] on social media. \\
\hline & EW5 & I would recommend brand [NAME] products to my friends on social media. \\
\hline & EW6 & $\begin{array}{l}\text { If my friends were looking to buy this kind of products or services, I would tell them trying brand } \\
\text { [NAME] on social media. }\end{array}$ \\
\hline \multirow{3}{*}{ Purchase Intention (PI) } & PI1 & $\begin{array}{l}\text { I would rather buy the products or brands implementing DSR Initiatives than the other existing } \\
\text { (competing) products or brands. }\end{array}$ \\
\hline & PI2 & I will purchase the brand [NAME]'s product next time I need a product. \\
\hline & PI3 & $\begin{array}{l}\text { I would like to recommend the products or brands implementing DSR Initiatives to friends or } \\
\text { other people in SNSs. }\end{array}$ \\
\hline
\end{tabular}




\section{4- Results and Discussions}

\section{4-1-Sample Profile}

An online self-administered questionnaire was employed to gather the data in this study. After passing the screening questions, respondents were asked to think of their most recent experience with any organisation's official Facebook fan page post that explicitly referred to the company's donations, charitable activity, volunteering, or local community initiatives. Next, the respondents were asked to complete the questionnaire based on their perception related to the specific DSR initiatives which they had identified from the Facebook posts.

After screening and validation, 214 valid survey questionnaires in total were selected for further analysis. Table 2 represents the demographic findings: males composed $47.3 \%$, while females composed $52.7 \%$ of total participants. The majority of the respondents, $31.4 \%$, were ages $26-35$, with $54 \%$ having undergraduate qualification. A high proportion of respondents, $38.1 \%$, reported spending 3-4 hours on social media daily. Most respondents, $77.9 \%$, indicated they believe that social media is a more convenient platform for participating in social responsibility initiatives than traditional platforms. Moreover, $87.1 \%$ responded that firms should engage stakeholders through social media to solve social and environmental issues through social media.

Table 2. Questionnaire respondent profiles

\begin{tabular}{|c|c|c|c|}
\hline Variable & Item & Frequency & Percentage (\%) \\
\hline \multirow{3}{*}{ Gender } & Male & 101 & 47.3 \\
\hline & & & \\
\hline & Female & 113 & 52.7 \\
\hline \multirow{5}{*}{ Age } & $18-25$ & 65 & 30.5 \\
\hline & $26-35$ & 67 & 31.4 \\
\hline & $36-45$ & 48 & 22.3 \\
\hline & $46-55$ & 25 & 11.6 \\
\hline & More than 55 years & 9 & 4.2 \\
\hline \multirow{3}{*}{ Education } & Below undergraduate & 12 & 5.7 \\
\hline & Undergraduate & 117 & 54.5 \\
\hline & Postgraduate & 85 & 39.8 \\
\hline \multirow{4}{*}{ Social media usage daily } & Less than 1 hour & 16 & 7.6 \\
\hline & 1 hour -2 hours & 43 & 20.1 \\
\hline & 3 hours -4 hours & 82 & 38.1 \\
\hline & More than 4 hours & 73 & 34.2 \\
\hline \multirow{3}{*}{$\begin{array}{l}\text { Is social media a more convenient } \\
\text { platform for you to participate in any } \\
\text { social responsibility initiatives, than the } \\
\text { traditional platforms? }\end{array}$} & Yes & 167 & 77.9 \\
\hline & No & 21 & 9.7 \\
\hline & Maybe & 27 & 12.4 \\
\hline \multirow{3}{*}{$\begin{array}{l}\text { Do you think firms should engage } \\
\text { stakeholders to solve social and } \\
\text { environmental issues through social } \\
\text { media? }\end{array}$} & Yes & 186 & 87.1 \\
\hline & No & 11 & 5.1 \\
\hline & Maybe & 17 & 7.8 \\
\hline
\end{tabular}

Note: $\mathrm{N}=214$; missing values are not present in the table

\section{4-2-Measurement Model}

A confirmatory factor analysis has been conducted to validate this study's structure of a set of observed variables. An overall goodness of fit analysis has been conducted for the model, whereas separate tests have been conducted for its significance in determining the assumed relationships between the different variables. The model comprised five constructs and 28 individual items. Table 3 shows the prominent indicators of the current study's measurement model. 
Table 3. Summary of measurement results

\begin{tabular}{|c|c|c|c|c|c|c|}
\hline Constructs and items & Loading & t-value & SE & $\alpha$ & Composite reliability & AVE \\
\hline Digital social responsibility & - & - & - & 0.852 & 0.842 & 0.695 \\
\hline DSR1 & 0.769 & - & - & - & - & - \\
\hline DSR2 & 0.850 & 13.751 & 0.073 & - & - & - \\
\hline DSR3 & 0.763 & 12.625 & 0.062 & - & - & - \\
\hline DSR4 & 0.833 & 13.412 & 0.074 & - & - & - \\
\hline DSR5 & 0.874 & 14.568 & 0.072 & - & - & - \\
\hline Consumer attitude & - & - & - & 0.832 & 0.846 & 0.741 \\
\hline ATT1 & 0.807 & - & - & - & - & - \\
\hline ATT2 & 0.747 & 14.214 & 0.069 & - & - & - \\
\hline ATT3 & 0.849 & 15.121 & 0.071 & - & - & - \\
\hline ATT4 & 0.904 & 20.142 & 0.072 & - & - & - \\
\hline ATT5 & 0.845 & 15.029 & 0.070 & - & - & - \\
\hline ATT6 & 0.712 & 14.085 & 0.068 & - & - & - \\
\hline Electronic word of mouth (eWOM) & - & - & - & 0.819 & 0.899 & 0.722 \\
\hline EW1 & 0.762 & - & - & - & - & - \\
\hline EW2 & 0.812 & 17.373 & 0.063 & - & - & - \\
\hline EW3 & 0.774 & 15.987 & 0.061 & - & - & - \\
\hline EW4 & 0.802 & 17.235 & 0.062 & - & - & - \\
\hline EW5 & 0.789 & 16.753 & 0.057 & - & - & - \\
\hline EW6 & 0.794 & 16.941 & 0.059 & - & - & - \\
\hline Purchase intention & - & - & - & 0.806 & 0.811 & 0.753 \\
\hline PI1 & 0.831 & - & - & - & - & - \\
\hline PI2 & 0.822 & 15.785 & 0.065 & - & - & - \\
\hline PI3 & 0.798 & 15.321 & 0.068 & - & - & - \\
\hline
\end{tabular}

Notes: DSR1, ATT1, EW1, and PI1 are fixed parameters

Table 3 shows that the value of Cronbach's $\alpha$ ranges from $0.806-0.852$ for each construct and its sequent subscales. This value measures the reliability of variables in the model. Because all the values are greater than 0.7, internal consistency of the model's constructs has been achieved. Further, the convergent and discriminant validities of the constructs have been evaluated. The validity of the former is assessed through three indices: composite reliability (CR), average variance extracted (AVE), and all factor loadings, for which the respective values should be more than $0.7,0.5$, and 0.7 , respectively [37]. For sufficient discriminant validity, one of the criteria is a high square root of AVE for each construct, compared to the correlation between that construct and other constructs in the research model. The AVE calculation also shows that the square root of AVE for each construct $(\mathrm{DSR}=0.834$; $\mathrm{ATT}=0.861 ; \mathrm{eWOM}=0.850$; $\mathrm{PI}=0.868$ ) is higher than the correlation between that construct and other constructs. Thus, the discriminant validity has been confirmed for all the constructs.

A satisfactory level of construct validity has also been achieved in the results, regarding convergent and divergent validities. This result indicates that the model's constructs are sufficiently fit to assess the structural model. The model fit's basic indices include Chi-square $=325.541 ; \mathrm{df}=164 ; \mathrm{CMIN} / \mathrm{df}=1.985 ; \mathrm{GFI}=0.919 ; \mathrm{NFI}=0.921 ; \mathrm{TLI}=0.927$; $\mathrm{CFI}=0.965$; and RMSEA $=0.038$. Thus, a satisfactory fit between the sample data and proposed model is confirmed for further testing of the hypotheses and evaluation of the structural model.

\section{4-3-Structural Model and Hypotheses Testing}

The structural model has been assessed by testing the hypotheses underlying the proposed research model. Path analysis has been performed to assess the causal relationships between constructs. The goodness-of-fit indicators of this model were Chi-square $=351.780 ; \mathrm{df}=164 ; \mathrm{CMIN} / \mathrm{df}=2.145 ; \mathrm{GFI}=0.917 ; \mathrm{NFI}=0.916 ; \mathrm{TLI}=0.922 ; \mathrm{CFI}=0.943$; and RMSEA $=0.041$. The cut-off values were met by all the indicators, which indicates the model is an appropriate fit. Table 4 provides a summary of the results of testing for this study's first six hypotheses, and shows the significance of relationships between the variables. 
Table 4. Hypotheses test results

\begin{tabular}{|c|c|c|c|c|}
\hline Hypothesis & Path & Coefficient & t-value & Result \\
\hline $\begin{array}{l}\text { H1: Digital social responsibility (DSR) initiatives have a direct effect } \\
\text { on consumers' attitude (ATT). }\end{array}$ & $\mathrm{DSR} \rightarrow \mathrm{ATT}$ & 0.408 & 6.945 & Accepted \\
\hline $\begin{array}{l}\text { H2: Digital social responsibility (DSR) initiatives have a direct effect } \\
\text { on electronic word of mouth (eWOM). }\end{array}$ & $\mathrm{DSR} \rightarrow \mathrm{eWOM}$ & 0.238 & 3.127 & Accepted \\
\hline $\begin{array}{l}\text { H3: Digital social responsibility (DSR) initiatives have a direct effect } \\
\text { on purchase intention (PI). }\end{array}$ & $\mathrm{DSR} \rightarrow \mathrm{PI}$ & 0.076 & 1.259 & Rejected \\
\hline $\begin{array}{l}\text { H4: Consumers' attitude (ATT) has a direct effect on electronic word } \\
\text { of mouth (eWOM). }\end{array}$ & $\mathrm{ATT} \rightarrow \mathrm{eWOM}$ & 0.378 & 4.988 & Accepted \\
\hline $\begin{array}{l}\text { H5: Consumers' attitude (ATT) has a direct effect on purchase } \\
\text { intention (PI). }\end{array}$ & $\mathrm{ATT} \rightarrow \mathrm{PI}$ & 0.333 & 5.012 & Accepted \\
\hline $\begin{array}{l}\text { H6: Electronic word of mouth (eWOM) has a direct effect on purchase } \\
\text { intention (PI). }\end{array}$ & $\mathrm{eWOM} \rightarrow \mathrm{PI}$ & 0.095 & 1.352 & Rejected \\
\hline
\end{tabular}

Notes: $* \mathrm{p}<0.05 ; * * \mathrm{p}<0.01 ; * * * \mathrm{p}<0.001$

Based on the path analysis outcomes, we accept $\mathrm{H} 1$ because perceived DSR significantly influenced ATT (H1: $\beta=0.41 ; p<0.001)$. Perceived DSR also significantly influenced by eWOM $(\mathrm{H} 2: \beta=0.24 ; \mathrm{p}<0.01)$ but not by PI (H3: $\beta=0.08 ; \mathrm{p}>0.05$ ). Thus, $\mathrm{H} 2$ has been accepted and $\mathrm{H} 3$ has been rejected. Further, there is a significant positive impact of ATT upon eWOM (H4: $\beta=0.38 ; \mathrm{p}<0.001)$ as well as on PI (H5: $\beta=0.33 ; \mathrm{p}<0.001)$. Therefore, $\mathrm{H} 4$ and H5 are both accepted. Lastly, the results imply that there is no significant impact of eWOM on PI (H6: $\beta=0.10 ; p>0.05$ ). Thus, H6 has been rejected.

To assess the mediating effect of DSR on eWOM and PI through ATT, the bootstrapping technique method has been employed. The outcomes of mediation testing demonstrate that DSR directly influences eWOM $(0.238 ; \mathrm{p}<0.001$; $95 \%$ CI $[0.145,0.368])$ and DSR indirectly influenced on eWOM via ATT $(0.154 ; \mathrm{p}<0.001 ; 95 \%$ CI $[0.123,0.295])$ which confirms the existence of the partial mediating effect. The findings additionally expose that DSR insignificantly directly influences PI $(0.08 ; 95 \%$ CI [-0.06, 0.12]), but that it significantly indirectly influences PI via ATT $(0.173 ; \mathrm{p}<$ $0.001 ; 95 \%$ CI $[0.13,0.30])$. As a result, the full mediation effect is confirmed. Table 5 summarizes the mediation analysis results with bootstrapping, and Figure 3 illustrates the summary of hypothesis testing.

Table 5. Outcomes of mediating effect testing

\begin{tabular}{ccccc}
\hline & Hypothesis & Direct effect (DE) & Indirect effect (IE) & Result \\
\hline H7 & DSR $\rightarrow$ ATT $\rightarrow$ eWOM & $0.238(* * *)$ & $0.154(* * *)$ & Partial Mediation \\
H8 & DSR $\rightarrow$ ATT $\rightarrow$ PI & $0.08($ n.s. $)$ & $0.173(* * *)$ & Full Mediation \\
\hline
\end{tabular}

Note: $* * *=\mathrm{p}<0.001 ; * *=\mathrm{p}<0.01 ; *=\mathrm{p}<0.05$; n.s. $=$ 'not significant'

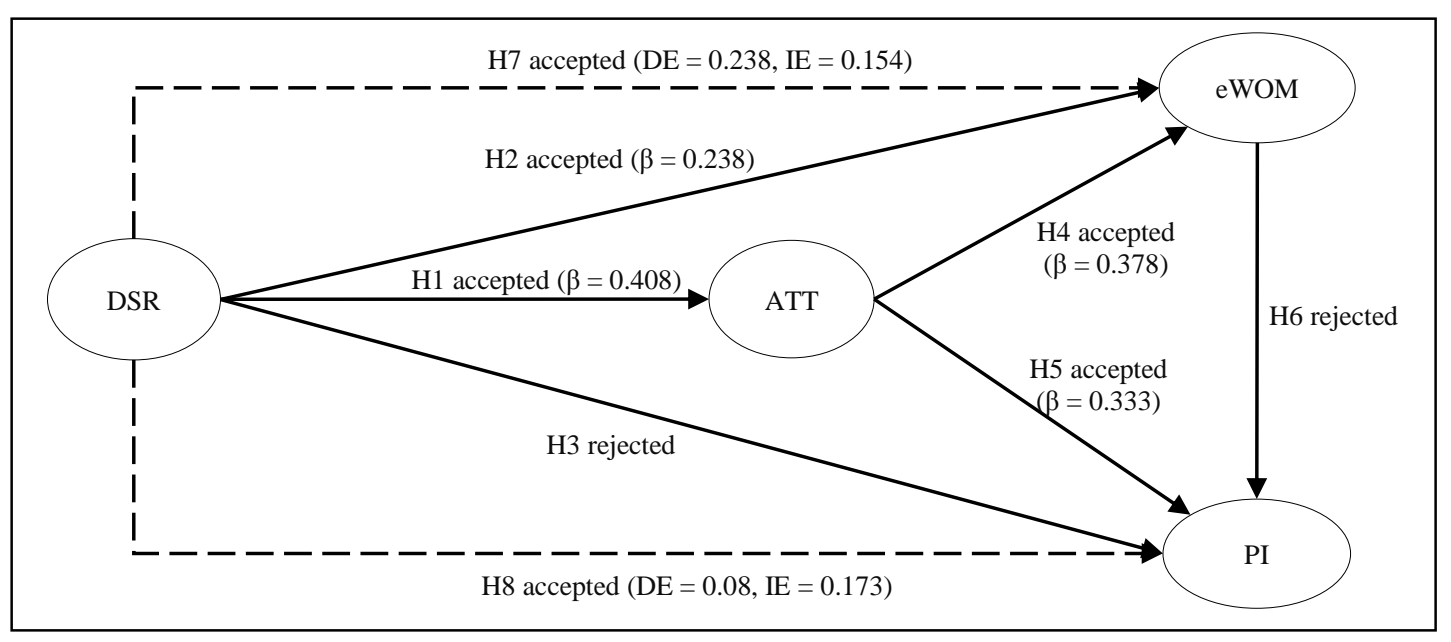

Figure 3. Summary of hypothesis testing

Prior empirical research focusing on digital social responsibility and its impact on customers' attitudes and behaviours in the social media context is comparatively scarce. Social media has become a vital avenue enabling firms to interact and engage with customers regarding social responsibility issues, initiatives, and activities. Although DSR seems to be a crucial strategy for businesses, researchers have not yet developed a strong understanding of the effects of DSR upon 
consumer attitude, eWOM, and purchase intention. To help close this research gap, the current study has analysed the effects of DSR on eWOM and purchase intention; moreover, it has analysed the mediating influence of consumer attitude in the associations between DSR, eWOM, and purchase intention.

Based on the data collection of 214 samples, this study's results have revealed that DSR positively influences consumer attitude and eWOM. This research finding aligns with the previous research by Fatma et al. [14] that DSR initiatives can positively impact customers' attitudes and lead to the spread of positive eWOM. The result also confirms the results from Vo et al. [38] that firms with improved CSR engagement will gain more positive word of mouth and less negative word of mouth in the social media context. Although this study finds no strong direct link between perceived DSR and purchase intention, the mediation analysis results show that DSR subsequently impacts consumers' purchase intention through influencing their attitude. This mediation result is consistent with Bianchi et al. [39], who have shown that perceived CSR has a significant indirect effect on purchase intention. DSR initiatives can thus yield a short-term impact, by encouraging purchase intentions.

DSR initiatives and activities can be realized as an effective approach to engage stakeholders with minimal investment in cost and time. Thus, businesses should consider taking DSR as a strategic implementation. However, firms should use segmentation strategy to identify customers for implementing DSR initiatives; moreover, a traditional social responsibility approach continues to play an important role in some segmentation because not all customers may have access to a digital platform. In practical application, DSR can be recognized as an applicable marketing initiative to build firms' positive brand identity. Social media advocacy seems to be a promising platform to disseminate information. In addition to customers, social media includes third-party cheerleaders, sometimes called 'brand advocates', who help in the promotion of organisations through their own social media channels. When such brand advocates like, comment on, and share firms' DSR initiatives via Facebook, firms can build brand identity through DSR.

This study presents beneficial implications for practitioners. Initially, businesses should realize that DSR efforts and investments can enhance positive attitudes among customers towards firms and contribute to positive eWOM. DSR represents an effective approach to drive positive customers' attitudes and word of mouth. Customers can participate in social responsibility activities via such digital platforms as social media, which many customers find more convenient than traditional media. The continuing advancement of social media technology may further lead to a challenge for businesses to design comprehensive social responsibility strategies both online and offline to satisfy their stakeholders and earn competitive advantage.

\section{5- Conclusion}

The purposes of this paper are to examine the impact of DSR on eWOM and purchase intention, and to examine the mediating role of consumer attitude in the social media context. The results indicate that perceived DSR is a significant determinant of eWOM and purchase intention. The results of mediation analysis have further revealed that consumer attitude partially mediates the effect of DSR on eWOM, and fully mediates the effect of DSR on purchase intention. This study provides empirical evidence and extends the body of knowledge regarding DSR in the context of social media.

The study includes a few limitations, which must be discussed. First, this study focused on the effect of digital social responsibility via social media by using Facebook as the representative of social networking sites (SNSs). Further research could examine the effects of DSR initiatives and activities on eWOM and purchase intention on other social networking platforms, such as Twitter, YouTube, Instagram, Tumblr, Flickr, Pinterest, Line, and so on. Second, the current study has included only a few constructs assumed to be influenced by DSR. Future empirical research could examine and test additional constructs, including customer loyalty, brand equity, and brand image. Third, because the samples have been collected in Thailand, generalization of the results should be conducted carefully. Different cultural characteristics may affect customers' perception of DSR. Further research should expand into cross-country data collection and comparison.

\section{6- Declarations}

\section{6-1-Author Contributions}

W.P. conceptualized and participated in study design, coordinated data collection, carried out the initial analyses, drafted the initial manuscript, and read and approved the manuscript. S.T. participated in study design; guided the methodology; coordinated and supervised data collection and analyses; and reviewed and edited the manuscript. Both authors read and approved the manuscript as submitted, and agree to be accountable for all aspects of the work.

\section{6-2-Data Availability Statement}

Due to the nature of this research, participants in this study have not agreed to be shared publicly; therefore, the data presented in this study are available on request from the corresponding author.

\section{6-3-Funding}

The authors received no financial support for the research, authorship, and/or publication of this article. 


\section{6-4- Conflicts of Interest}

The authors declare that there is no conflict of interests regarding the publication of this manuscript. In addition, the ethical issues, including plagiarism, informed consent, misconduct, data fabrication and/or falsification, double publication and/or submission, and redundancies have been completely observed by the authors.

\section{7- References}

[1] Carroll, A. B. (2017). A three-dimensional conceptual model of corporate performance. Corporate Social Responsibility, 4(4), 37-45. doi:10.5465/amr.1979.4498296.

[2] Öberseder, M., Schlegelmilch, B. B., \& Murphy, P. E. (2013). CSR practices and consumer perceptions. Journal of Business Research, 66(10), 1839-1851. doi:10.1016/j.jbusres.2013.02.005.

[3] Chu, S. C., \& Chen, H. T. (2019). Impact of consumers' corporate social responsibility-related activities in social media on brand attitude, electronic word-of-mouth intention, and purchase intention: A study of Chinese consumer behavior. Journal of Consumer Behaviour, 18(6), 453-462. doi:10.1002/cb.1784.

[4] Camilleri, M. A. (2019). The SMEs' technology acceptance of digital media for stakeholder engagement. Journal of Small Business and Enterprise Development, 26(4), 504-521. doi:10.1108/JSBED-02-2018-0042.

[5] Kucukemiroglu, S., \& Kara, A. (2015). Online word-of-mouth communication on social networking sites: An empirical study of Facebook users. International Journal of Commerce and Management, 25(1), 2-20. doi:10.1108/IJCoMA-11-2012-0070.

[6] We are Social. "Digital in 2020: Global Digital Overview." (2020). Available online: https://wearesocial.com/digital-2020 (accessed on March 2021).

[7] Leesa-Nguansuk, Suchit. "Thailand Tops Global Digital Rankings.” (2019). Available online: https://www.bangkokpost.com/tech/1631402/thailand-tops-global-digital-rankings (accessed on March 2021).

[8] Lee, J. W., \& Kwag, M. (2017). Corporate Marketing Strategy Using Social Media: A Case Study of the Ritz-Carlton Seoul. The Journal of Asian Finance, Economics and Business, 4(1), 79-86. doi:10.13106/jafeb.2017.vol4.no1.79.

[9] CHAE, M. J. (2020). The Effects of Message Tone and Formats of CSR Messages on Engagement in Social Media. Journal of Asian Finance, Economics and Business, 7(10), 501-512. doi:10.13106/jafeb.2020.vol7.no10.501.

[10] Du, S., \& Vieira, E. T. (2012). Striving for Legitimacy through Corporate Social Responsibility: Insights from Oil Companies. Journal of Business Ethics, 110(4), 413-427. doi:10.1007/s10551-012-1490-4.

[11] Golob, U., Podnar, K., Elving, W. J., Ellerup Nielsen, A., Thomsen, C., \& Schultz, F. (2013). CSR communication: Quo vadis? Corporate Communications: An International Journal, 18(2), 176-192. doi:10.1108/13563281311319472.

[12] Farzin, M., \& Fattahi, M. (2018). eWOM through social networking sites and impact on purchase intention and brand image in Iran. Journal of Advances in Management Research, 15(2), 161-183. doi:10.1108/JAMR-05-2017-0062.

[13] Tao, W., \& Wilson, C. (2015). Fortune 1000 communication strategies on Facebook and Twitter. Journal of Communication Management, 19(3), 208-223. doi:10.1108/JCOM-01-2013-0004.

[14] Fatma, M., Ruiz, A. P., Khan, I., \& Rahman, Z. (2020). The effect of CSR engagement on eWOM on social media. International Journal of Organizational Analysis, 28(4), 941-956. doi:10.1108/IJOA-10-2019-1895.

[15] Eberle, D., Berens, G., \& Li, T. (2013). The Impact of Interactive Corporate Social Responsibility Communication on Corporate Reputation. Journal of Business Ethics, 118(4), 731-746. doi:10.1007/s10551-013-1957-y.

[16] Kakirala, A. K., \& Singh, D. P. (2020). The Mediating Role of Social Media in Tourism: An eWOM Approach. Journal of Asian Finance, Economics and Business, 7(11), 381-391. doi:10.13106/jafeb.2020.vol7.no11.381.

[17] Bhattacharya, C. B., \& Sen, S. (2004). Doing better at doing good: When, why, and how consumers respond to corporate social initiatives. California Management Review, 47(1), 9-24. doi:10.2307/41166284.

[18] Lacey, R., \& Kennett-Hensel, P. A. (2010). Longitudinal Effects of Corporate Social Responsibility on Customer Relationships. Journal of Business Ethics, 97(4), 581-597. doi:10.1007/s10551-010-0526-x.

[19] Litvin, S. W., Goldsmith, R. E., \& Pan, B. (2008). Electronic word-of-mouth in hospitality and tourism management. Tourism Management, 29(3), 458-468. doi:10.1016/j.tourman.2007.05.011.

[20] Hennig-Thurau, T., Gwinner, K. P., Walsh, G., \& Gremler, D. D. (2004). Electronic word-of-mouth via consumer-opinion platforms: What motivates consumers to articulate themselves on the Internet? Journal of Interactive Marketing, 18(1), 38-52. doi:10.1002/dir.10073.

[21] Abzari, M., Ghassemi, R. A., \& Vosta, L. N. (2014). Analysing the Effect of Social Media on Brand Attitude and Purchase Intention: The Case of Iran Khodro Company. Procedia - Social and Behavioral Sciences, 143, 822-826. doi:10.1016/j.sbspro.2014.07.483. 
[22] Lim, X. J., Mohd Radzol, A. R. bt, Cheah, J.-H. (Jacky), \& Wong, M. W. (2017). The Impact of Social Media Influencers on Purchase Intention and the Mediation Effect of Customer Attitude. Asian Journal of Business Research, 7(2), 19-36. doi:10.14707/ajbr.170035.

[23] Boone, L. E., \& Kurtz, D. L. (2004) Contemporary Marketing, Fifteenth Edition. Thomson South-Western Publishing.

[24] Phuong, N. N. D., \& Dat, N. T. (2017). The Effect of Country-of-Origin on Customer Purchase Intention: A Study of Functional Products in Vietnam. The Journal of Asian Finance, Economics and Business, 4(3), 75-83. doi:10.13106/jafeb.2017.vol4.no3.75.

[25] Bianchi, E., Bruno, J. M., \& Sarabia-Sanchez, F. J. (2019). The impact of perceived CSR on corporate reputation and purchase intention. European Journal of Management and Business Economics, 28(3), 206-221. doi:10.1108/EJMBE-12-2017-0068.

[26] Green, T., \& Peloza, J. (2014). Finding the right shade of green: The effect of advertising appeal type on environmentally friendly consumption. Journal of Advertising, 43(2), 128-141. doi:10.1080/00913367.2013.834805.

[27] CREYER, E. H., \& ROSS, W. T. (1997). Tradeoffs Between Price and Quality: How a Value Index Affects. Journal of Consumer Affairs, 31(2), 280-302. doi:10.1111/j.1745-6606.1997.tb00392.x.

[28] See-To, E. W. K., \& Ho, K. K. W. (2014). Value co-creation and purchase intention in social network sites: The role of electronic Word-of-Mouth and trust - A theoretical analysis. Computers in Human Behavior, 31(1), 182-189. doi:10.1016/j.chb.2013.10.013.

[29] Anderson, J. C., \& Gerbing, D. W. (1988). Structural Equation Modeling in Practice: A Review and Recommended Two-Step Approach. Psychological Bulletin, 103(3), 411-423. doi:10.1037/0033-2909.103.3.411.

[30] Kline, R. B. (2015). Principles and practice of structural equation modeling. Guilford publications.

[31] Butt, I. (2016). Corporate Social Responsibility and Consumer Buying Behavior in Emerging Market: A Mixed Method Study. International Journal of Business and Management, 11(7), 211. doi:10.5539/ijbm.v11n7p211.

[32] Mar García-de los Salmones, M. del, Herrero, A., \& Martínez, P. (2021). Determinants of Electronic Word-of-Mouth on Social Networking Sites about Negative News on CSR. Journal of Business Ethics, 171(3), 583-597. doi:10.1007/s10551-020-044669.

[33] Kwok, L., Mao, Z. (Eddie), \& Huang, Y. K. (2019). Consumers' electronic word-of-mouth behavioral intentions on Facebook: Does message type have an effect? Tourism and Hospitality Research, 19(3), 296-307. doi:10.1177/1467358417742684.

[34] Tien, D. H., Amaya Rivas, A. A., \& Liao, Y. K. (2019). Examining the influence of customer-to-customer electronic word-ofmouth on purchase intention in social networking sites. Asia Pacific Management Review, 24(3), $238-249$. doi:10.1016/j.apmrv.2018.06.003.

[35] Rovinelli, R. J., \& Hambleton, R. K. (1977). On the Use of Content Specialists in the Assessment of Criterion-Referenced Test Item Validity. Dutch Journal of Educational Research, 2, 49-60.

[36] Turner, R. C., \& Carlson, L. (2003). Indexes of Item-Objective Congruence for Multidimensional Items. International Journal of Testing, 3(2), 163-171. doi:10.1207/s15327574ijt0302_5.

[37] Awang, Z. (2015). SEM Made Simple: A Gentle Approach to Learning Structural Equation Modelling. In MPWS Rich Publication (Vol. 1, Issue 3). MPWS Rich Publication.

[38] Vo, T. T., Xiao, X., \& Ho, S. Y. (2019). How Does Corporate Social Responsibility Engagement Influence Word of Mouth on Twitter? Evidence from the Airline Industry. Journal of Business Ethics, 157(2), 525-542. doi:10.1007/s10551-017-3679-z.

[39] Bianchi, E., Bruno, J. M., \& Sarabia-Sanchez, F. J. (2019). The impact of perceived CSR on corporate reputation and purchase intention. European Journal of Management and Business Economics, 28(3), 206-221. doi:10.1108/EJMBE-12-2017-0068. 